\begin{tabular}{|l|l|l||}
\hline \multicolumn{2}{|c|}{ PublisherInfo } \\
\hline \hline PublisherName & $:$ & BioMed Central \\
\hline \hline PublisherLocation & $:$ & London \\
\hline \hline PublisherImprintName & $:$ & BioMed Central \\
\hline \hline
\end{tabular}

\title{
Water bug genome
}

\begin{tabular}{|l|l|l||}
\hline \multicolumn{2}{|c|}{ ArticleInfo } \\
\hline \hline ArticleID & $:$ & 4028 \\
\hline \hline ArticleDOI & $:$ & $10.1186 /$ gb-spotlight-20010327-03 \\
\hline \hline ArticleCitationID & $:$ & spotlight-20010327-03 \\
\hline \hline ArticleSequenceNumber & $:$ & 99 \\
\hline \hline ArticleCategory & $:$ & Research news \\
\hline ArticleFirstPage & $:$ & 1 \\
\hline \hline ArticleLastPage & $:$ & 2 \\
\hline \hline & $:$ & RegistrationDate : 2001-03-27 \\
ArticleHistory & $:$ & OnlineDate \\
\hline \hline ArticleCopyright & $:$ & BioMed Central Ltd2001 -03-27 \\
\hline \hline ArticleGrants & $:$ & \\
\hline \hline ArticleContext & $:$ & 130592211 \\
\hline \hline
\end{tabular}




\section{Jonathan B Weitzman}

Email: jonathanweitzman@hotmail.com

Caulobacter crescentus is a Gram-negative bacterium that exhibits cell differentiation, asymmetric division and cordinated cell-cycle progression. In the March 27 Proceedings of the National Academy of Sciences USA, Nierman et al. report the complete genome sequence of C. crescentus (Proc Natl Acad Sci USA 2001, 98:4136-4141). The sequence was assembled by whole-genome random sequencing. The single $C$. crescentus chromosome contains about 4 megabases of DNA and encodes 3,767 genes. Cellcycle progression is dependent on two-component signal-transduction proteins, and these are abundant in the genome (105 genes). Many of these signalling proteins function, together with outer membrane channel transporters and metabolic enzymes, to allow adaptability to environmental fluctuations and low-nutrient conditions: for example, they sense and respond to intracellular oxygen and redox states. Nierman et al. also suggest that DNA methylation in intergenic regions plays a role in cell-cycle regulation. Analysis of the $C$. crescentus genome should provide insights into the biology of related bacteria, such as the human pathogens Rickettsia prowazekii and Brucella abortus.

\section{References}

1. GenomeAtlas for Caulobacter crescentus, [http:/www.cbs.dtu.dk/services/GenomeAtlas/ Caulobacter/cresentus/Strain/caulo.genomeatlas.html]

2. Proceedings of the National Academy of Sciences, [http://www.pnas.org]

3. Global analysis of the genetic network controlling a bacterial cell cycle.

4. Rickettsia prowazekii,

5. Brucella abortus, [http://www.medinfo.ufl.edu/year2/mmid/bms5300/bugs/brucella.html] 